\title{
Solid State Characterization for a Comparative Evaluation of the Biofield Energy Treated and Un-treated Ascorbic Acid
}

\author{
Alice Branton ${ }^{1}$, Mahendra Kumar Trivedi ${ }^{1}$, Dahryn Trivedi ${ }^{1}$, Gopal Nayak ${ }^{1}$ and Snehasis Jana ${ }^{2 *}$ \\ ${ }^{1}$ Trivedi Global, Inc., Henderson, USA \\ ${ }^{2}$ Trivedi Science Research Laboratory Pvt. Ltd., Thane (W), India \\ *Corresponding author: Snehasis Jana, Trivedi Science Research Laboratory Pvt. Ltd., Thane (W), India
}

\begin{abstract}
Ascorbic acid is a water-soluble vitamin that mainly acts as an antioxidant and helps in controlling and maintaining various body functions. The study was designed to analyze the impact of the Trivedi Effect ${ }^{\circledR}$-Consciousness Energy Healing Treatment on the physicochemical and thermal properties of ascorbic acid by using sophisticated analytical techniques. For the study, the test sample ascorbic acid was divided into the control and treated sample. To the control sample, no Biofield Energy Treatment was provided. However, the treated sample received the Biofield Energy Treatment remotely by the renowned Biofield Energy Healer, Alice Branton, USA. The PXRD peak intensities and crystallite sizes of the treated sample significantly altered ranging from $-78.43 \%$ to $1168.06 \%$ and $-62.38 \%$ to $126.83 \%$, respectively; along with $24.99 \%$ decrease in the average crystallite size as compared to the control sample. The particle size values in the treated sample by $9.59 \%\left(d_{10}\right), 21.63 \%\left(d_{50}\right), 16.55 \%\left(d_{90}\right)$, and $17.97 \%\{\mathrm{D}(4,3)\}$, respectively; hence the specific surface area was increased by $16.67 \%$ compared to the control sample. The weight loss was increased by $6.67 \%$; however, the residue amount was found to be significantly decreased by $28.59 \%$ in the treated sample compared to the control sample. The $\mathrm{T}_{\max }$ of the treated sample corresponding to $1^{\text {st }}$ and $2^{\text {nd }}$ peaks were decreased by $0.33 \%$ and $4.09 \%$, respectively as compared to the control sample. Moreover, the latent heat of fusion was significantly increased by $13.74 \%$ as compared to the control sample. Besides, the degradation temperature and $\Delta \mathrm{H}_{\text {decomposition }}$ of the treated sample were significantly reduced by $6.54 \%$ and $20.46 \%$, respectively, as compared to the control sample. The Trivedi Effect ${ }^{\circledR}$ might help in forming a novel polymorphic form of ascorbic acid that may also prove to be more soluble, absorbable, and bioavailable than the untreated sample. Thus, the Trivedi Effect ${ }^{\circledast}$ might be considered as a novel approach for designing the more efficacious ascorbic acid containing nutraceutical/pharmaceutical formulations.
\end{abstract}

Keywords: Ascorbic acid; Consciousness Energy Healing Treatment; The Trivedi Effect ${ }^{\circledR}$; PXRD; Particle size; TGA/DTG

\section{Introduction}

Vitamins play an important role in different biochemical and normal physiological processes in the body. They are the essential nutrients, and most of them cannot be synthesized in the body. Thus, some vitamins must be incorporated into the diet as important supplementation. On the basis of solubility, they are classified as water soluble (C and B complexes) and fat-soluble vitamins (A, D, E, and $\mathrm{K}$ ). Most of the body functions are controlled and maintained by vitamin C and it works as a significant antioxidant [1]. In 1928, it was first isolated with their numerous biochemical and pharmacokinetic properties, its functions and its significant role in neurophysiology. Vitamin C maintains the oxidation and reduction process (redox).
Thus, the possible role of vitamin $\mathrm{C}$ for the treatment of a large number of disorders like diabetes, atherosclerosis, common cold, cataracts, glaucoma, macular degeneration, stroke, heart diseases, cancer, autoimmune diseases, and chronic degenerative diseases [2]. Vitamin C helps in the synthesis and metabolism of tyrosine, ascorbic acid, tryptophan, proline, hydroxylation of glycine, lysine, carnitine, and catecholamine. Vitamin C is involved in the physiology of the nervous system and plays a vital role in the modulation of neurotransmission. It also includes the support and the structure of the neurons, the processes of differentiation, maturation, and neuronal survival along with catecholamine 
synthesis. The role of vitamin C in skin health has been well defined $[3,4]$. It lowers blood cholesterol levels by increasing the conversion of cholesterol into bile acids. Further, it increases the iron absorption in the gut by reducing the ferric to the ferrous state. Vitamin C worked as a significant antioxidant agent, thus have deleterious effects of free radicals, pollutants, and toxins. Vitamin C deficiency in the body can result in bleeding gums, scurvy, anemia, infections, capillary hemorrhage, muscle degeneration, delayed wound healing, atherosclerotic plaques, low immunity, and neurotic disturbances [5]. Rich sources of vitamin $\mathrm{C}$ are citrus fruits, turnip, green peppers, tomatoes, strawberries, broccoli, Brussels sprouts, red peppers, Indian gooseberry, and other leafy vegetables. Vitamin $C$ is a neutrally charged molecule that can be protonated and become ascorbate. Thus its absorption mechanism, dissolution, transport factors, tissue distribution, pharmacokinetic properties, etc. depends upon its physiochemical properties [6]. Therefore, to increase the physiochemical profile such as particle size, crystalline structure, crystallite size, surface area, etc., to achieve maximum biological activities, research has been carried to alter the physicochemical properties.

Putative energy fields (also known as Biofield) have defied measurement that involves putative energy fields, which are based on the concept that human beings are infused with a subtle form of energy [7]. Thus, every human has the capability to harness energy from the universe and can transfer it to any living organism(s) or nonliving object(s) around the globe. Biofield Energy Healing has been considered as Energy Therapy and was accepted by the National Center for Complementary and Alternative Medicine (NCCAM) [8] against many diseases. NCCAM recommend and accepted various types of Energy therapies under CAM due to several advantages in addition to other therapies, medicines and practices, i.e., Ayurvedic medicine, traditional Chinese herbs and medicines, yoga, Tai Chi, Qi Gong, chiropractic/osteopathic manipulation, massage, meditation, homeopathy, acupressure, acupuncture, hypnotherapy, healing touch, movement therapy, pilates, rolfing structural integration, aromatherapy, Reiki, cranial sacral therapy, etc. $[9,10]$. The Consciousness Energy Healing Treatment (the Trivedi Effect ${ }^{\circ}$ ) has been described worldwide with remarkable results nonliving materials and in living organisms. Biofield Energy Healing Treatment significantly altered the physicochemical and thermal properties of many organic/pharmaceutical compounds [11-14], alter the characteristics in microbiology $[15,16]$, agriculture science $[17,18]$, metals, ceramics, and polymers [19-21], biotechnology [22], bone and skin health, and nutraceuticals [23-26]. Thus, this study was also aimed to analyze the impact of the Biofield Energy Healing Treatment on the physicochemical and thermal properties of ascorbic acid by using various analytical techniques.

\section{Materials and Methods}

\section{Chemicals and Reagents}

The test sample ascorbic acid (Alfa Aesar, India) and the other chemicals used during the experiments were also purchased from India.

\section{Consciousness Energy Healing Treatment Strategies}

The test sample ascorbic acid was divided into two equal parts and termed as the control and Biofield Energy Treated sample. To the control sample, no Biofield Energy Treatment was provided. But, the control ascorbic acid sample, was treated with a "sham" healer who did not have any knowledge about the Biofield Energy Treatment. However, the treated part of ascorbic acid was received the Trivedi Effect ${ }^{\circ}$ - Consciousness Energy Healing Treatment remotely (for 3 minutes) under standard laboratory conditions by the renowned Biofield Energy Healer, Alice Branton, USA. This Energy Treatment was provided through the healer's unique energy transmission process, to the test sample. After the treatment, both samples were kept in sealed conditions and characterized using sophisticated analytical techniques.

\section{Characterization}

The powder X-ray diffraction (PXRD) analysis of ascorbic acid powder sample was performed with the help of Rigaku MiniFlexII Desktop X-ray diffractometer (Japan) [27,28]. The average crystallites size was calculated using the Scherrer's formula (1):

$$
\mathrm{G}=\mathrm{k} \lambda / \beta \cos \theta
$$

Where $\mathrm{k}$ is the equipment constant, $\mathrm{G}$ is the crystallite size in $\mathrm{nm}$, $\beta$ is the full-width at half maximum, $\lambda$ is the radiation wavelength, and $\theta$ is the Bragg angle [29].

The particle size analysis (PSA) was performed using Malvern Mastersizer 2000, (UK) using the wet method [30,31]. Similarly, the differential scanning calorimetry (DSC) analysis of ascorbic acid was performed with the help of DSC Q200, TA instruments. The thermogravimetric analysis/ differential thermogravimetric analysis (TGA/DTG) of ascorbic acid were obtained with the help of TGA Q50 TA instruments [32].

The \% change in crystallite size, peak intensity, particle size, specific surface area, melting point, weight loss, latent heat, and the maximum thermal degradation temperature of the Biofield Energy Treated sample was calculated compared with the control sample using the following equation 2 :

$$
\% \text { change }=\frac{[\text { Treated }- \text { Control }]}{\text { Control }} \times 100
$$

\section{Results and Discussion \\ Powder X-ray Diffraction (PXRD) Analysis}

The powder XRD diffractograms of the control and treated ascorbic acid samples are shown in (Figure 1).

The control and treated samples showed sharp and intense peaks in their diffractograms, which indicated their crystalline nature. The further analysis regarding the Bragg's angle, relative intensities, and crystallite sizes corresponding to those peaks were given in (Table 1) for both the samples. 

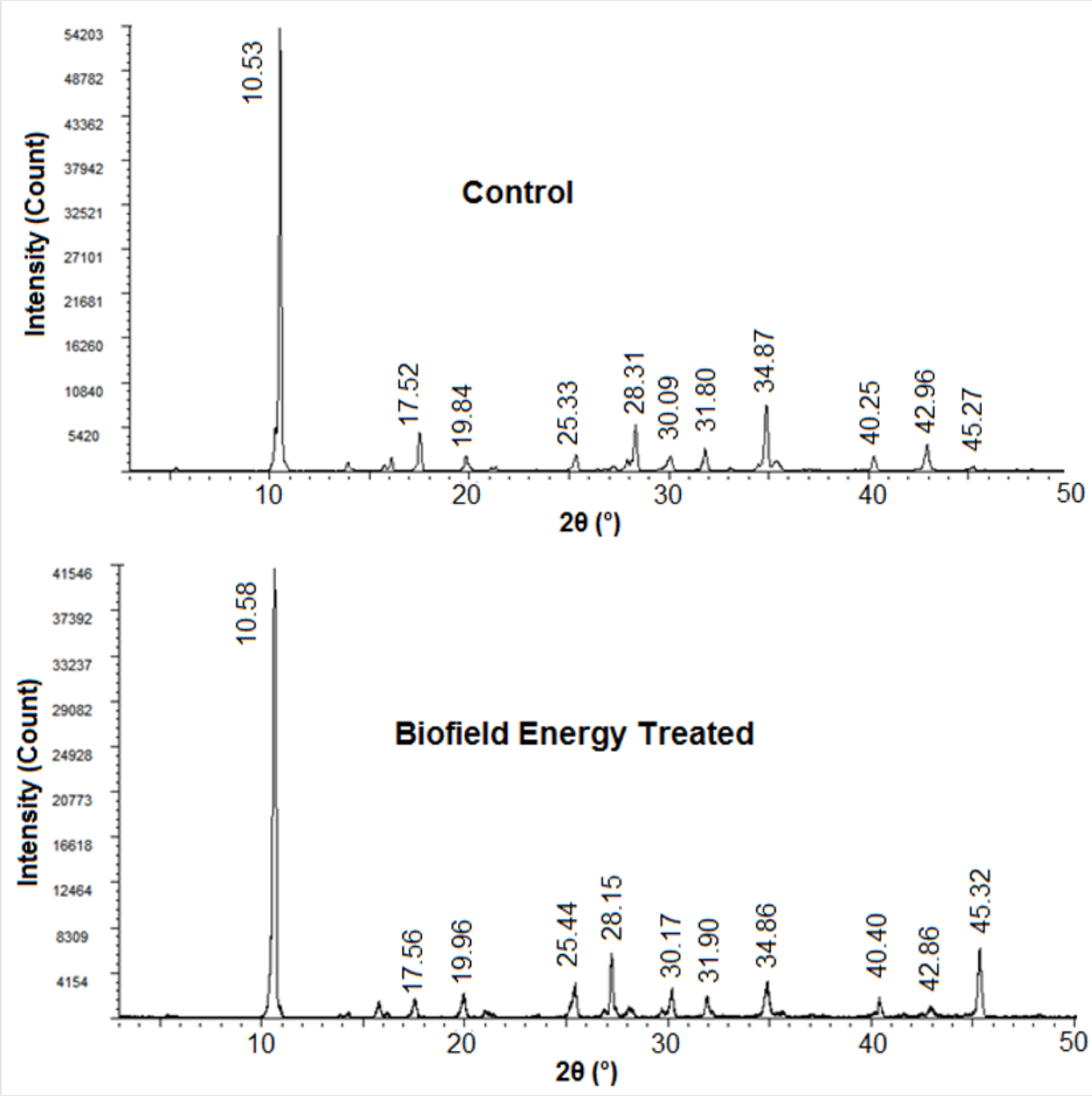

Figure 1: PXRD diffractograms of the control and treated ascorbic acid.

Table 1: PXRD data for the control and treated ascorbic acid.

\begin{tabular}{|cccccccccc|}
\hline \multirow{2}{*}{ Entry No. } & \multicolumn{2}{c}{ Bragg angle $(\mathbf{} \mathbf{2} \boldsymbol{\theta}$ ) } & \multicolumn{3}{c}{ Intensity (cps) } & \multicolumn{3}{c|}{ Crystallite size (G, nm) } \\
\cline { 2 - 9 } & Control & Treated & Control & Treated & \% Change & Control & Treated & \% Change \\
\hline 1 & 10.53 & 10.58 & 4581 & 988 & -78.43 & 699 & 339 & -51.50 \\
2 & 17.52 & 17.56 & 633 & 254 & -59.87 & 574 & 360 & -37.28 \\
3 & 19.84 & 19.96 & 341 & 328 & -3.81 & 623 & 335 & -46.23 \\
4 & 25.33 & 25.44 & 184 & 452 & 145.65 & 822 & 402 & -51.09 \\
5 & 28.31 & 28.15 & 863 & 227 & -73.70 & 622 & 234 & -62.38 \\
6 & 30.09 & 30.17 & 404 & 395 & -2.23 & 287 & 651 & 126.83 \\
7 & 31.80 & 31.90 & 321 & 330 & 2.80 & 764 & 604 & -20.94 \\
8 & 34.87 & 34.86 & 976 & 536 & -45.08 & 583 & 359 & -38.42 \\
9 & 40.25 & 40.40 & 262 & 153 & -41.60 & 591 & 851 & 43.99 \\
10 & 42.96 & 42.86 & 334 & 165 & -50.60 & 760 & 305 & -59.87 \\
11 & 45.27 & 45.32 & 72 & 913 & 1168.06 & 379 & 589 & 55.41 \\
\hline
\end{tabular}

The analysis revealed the alterations in the Bragg's angles of the peaks of the Biofield Energy Treated sample as compared to the control sample. Besides, the peak intensities of the Biofield Energy Treated ascorbic acid sample was significantly altered in the range from $-78.43 \%$ to $1168.06 \%$ in comparison to the control sample. Similarly, the Biofield Energy Treated ascorbic acid sample showed $-62.38 \%$ to $126.83 \%$ changes in the crystallite sizes corresponding to the characteristic peaks as compared to the control sample. Also, the average crystallite size of the Biofield Energy Treated sample (457.18nm) was significantly reduced by $24.99 \%$ as compared to the control sample $(609.45 \mathrm{~nm})$. Nowadays, the Biofield Energy Treatment has been reported to impact the crystal morphology and crystalline structure of the compounds by altering the Bragg's angle, peak intensities and crystallite sizes, thereby may form a new 
polymorph of the compound [33,34]. Thus, the study indicated the significant alterations in the crystallite size and peak intensities of the treated sample that might occur because of the formation of a new polymorph of ascorbic acid. It was reported that the physical modifications of the drug moiety such as altering the crystal habit like polymorphs might be used to improve the solubility and bioavailability profile of drug [35]. Hence, the Biofield Energy Treated ascorbic acid might be more soluble and bioavailable as compared to the untreated sample.

\section{Particle Size Analysis (PSA)}

The particle size analysis of both the samples was presented in (Table 2). The analysis revealed that the particle size distributions of the Biofield Energy Treated ascorbic acid sample at $d_{10}, d_{50}, d_{90}$, and $\mathrm{D}(4,3)$ were significantly reduced by $9.59 \%, 21.63 \%, 16.55 \%$, and $17.97 \%$, respectively, compared to the control sample.

Table 2: Particle size distribution of the control and treated ascorbic acid.

\begin{tabular}{|c|c|c|c|c|c|}
\hline Parameter & $d_{10}(\mu \mathrm{m})$ & $d_{50}(\mu \mathrm{m})$ & $d_{90}(\mu \mathrm{m})$ & $\mathrm{D}(4,3)(\mu \mathrm{m})$ & $\operatorname{SSA}\left(\mathrm{m}^{2} / \mathrm{g}\right)$ \\
\hline Control & 68.37 & 283.48 & 638.77 & 321.12 & 0.042 \\
\hline Biofield Treated & 61.81 & 222.17 & 533.05 & 263.40 & 0.049 \\
\hline Percent change (\%) & -9.59 & -21.63 & -16.55 & -17.97 & 16.67 \\
\hline
\end{tabular}

$\mathrm{d}_{10}, \mathrm{~d}_{50}$, and $\mathrm{d}_{90}$ : particle diameter corresponding to $10 \%, 50 \%$, and $90 \%$ of the cumulative distribution, SSA: the specific surface area, and $\mathrm{D}(4,3)$ : the average mass-volume diameter.

Besides, the decrease in particle size of the treated sample might influence the surface area of the Biofield Energy Treated sample $\left(0.049 \mathrm{~m}^{2} / \mathrm{g}\right)$, which was observed to be increased by $16.67 \%$ as compared with the SSA of the control sample $\left(0.042 \mathrm{~m}^{2} / \mathrm{g}\right)$. The particle size distribution of drug plays a vital role in the performance of the drug in terms of dissolution, absorption, and bioavailability inside the body [36,37]. It was reported that the reduction in particle size of drug followed by the increase in its surface area might help in enhancing the absorption and bioavailability profile of drug [38]. Thus, it is anticipated that the Biofield Energy Treated ascorbic acid might help in improving the bioavailability of the drug in formulation development as compared to the untreated ascorbic acid.

\section{Thermal Gravimetric Analysis (TGA)/ Differential Thermogravimetric Analysis (DTG)}

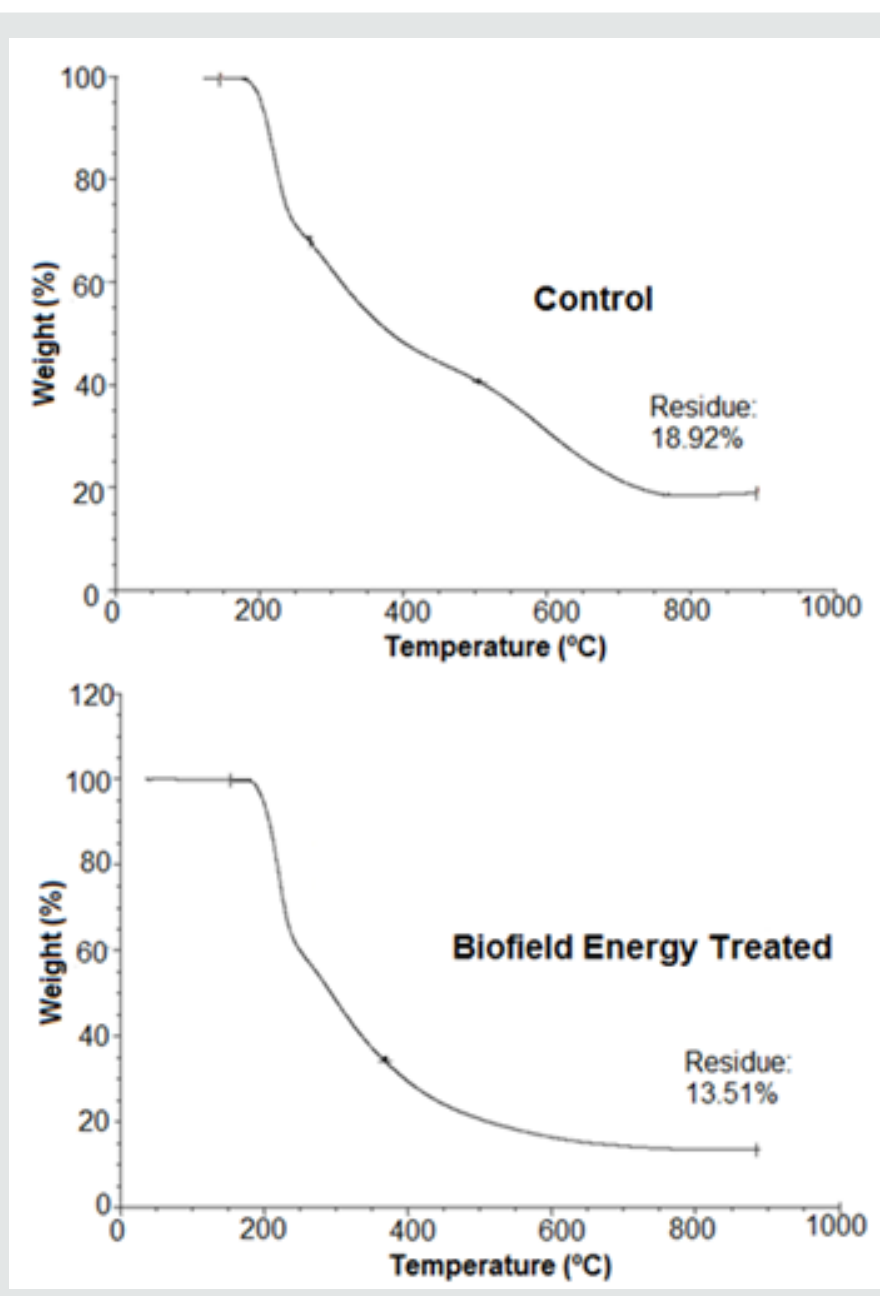

Figure 2: TGA thermograms of the control and treated ascorbic acid. 
The thermal stability profile of the control and Biofield Energy Treated samples were analysed using the TGA/DTG analytical technique. The literature stated that ascorbic acid is stable until $\sim 200{ }^{\circ} \mathrm{C}$. Moreover, it was also reported that the residue is composed of the mixture of non-decomposed ascorbic acid and its carbonaceous residues [39]. The TGA thermograms of the control and treated ascorbic acid samples (Figure 2) were found to be in concordance with the literature. There further analysis revealed that the Biofield Energy Treated sample showed $86.49 \%$ total weight loss, which was observed to be increased by $6.67 \%$ as compared to the total weight loss of the control sample (81.08\%). However, the residue amount of the Biofield Energy Treated sample was also reduced by $28.59 \%$ (Table 3 ) as compared to the control sample. It showed a decrease in the thermal stability of the Biofield Energy Treated sample as compared to the control sample.

Table 3: TGA/DTG data of the control and treated samples of ascorbic acid.

\begin{tabular}{|cccccc|}
\hline \multirow{2}{*}{ Sample } & \multicolumn{2}{c}{ TGA } & \multicolumn{3}{c|}{ DTG T $_{\text {max }}$ ( $^{\mathbf{}}$ C) } \\
\cline { 2 - 7 } & Total weight loss (\%) & Residue \% & Peak 1 & Peak 2 & Peak 3 \\
\hline Control & 81.08 & 18.92 & 220.51 & 323.15 & 602.50 \\
Biofield Energy Treated & 86.49 & 13.51 & 219.77 & 309.92 & - \\
\% Change & 6.67 & -28.59 & -0.33 & -4.09 & - \\
\hline
\end{tabular}

Besides, the DTG thermogram of the control sample contains three peaks, although only two peaks were observed in the thermogram of the Biofield Energy Treated ascorbic acid sample (Figure 3). Besides, the maximum degradation temperature $\left(\mathrm{T}_{\max }\right)$ of the $1^{\text {st }}$ and $2^{\text {nd }}$ peak of the treated sample was observed to be decreased by $0.33 \%$ and $4.09 \%$ as compared to the control sample. Overall, the TGA/DTG studies indicated the decrease in the thermal degradation pattern and thermal stability of the Biofield Energy Treated sample as compared to the untreated ascorbic acid sample.
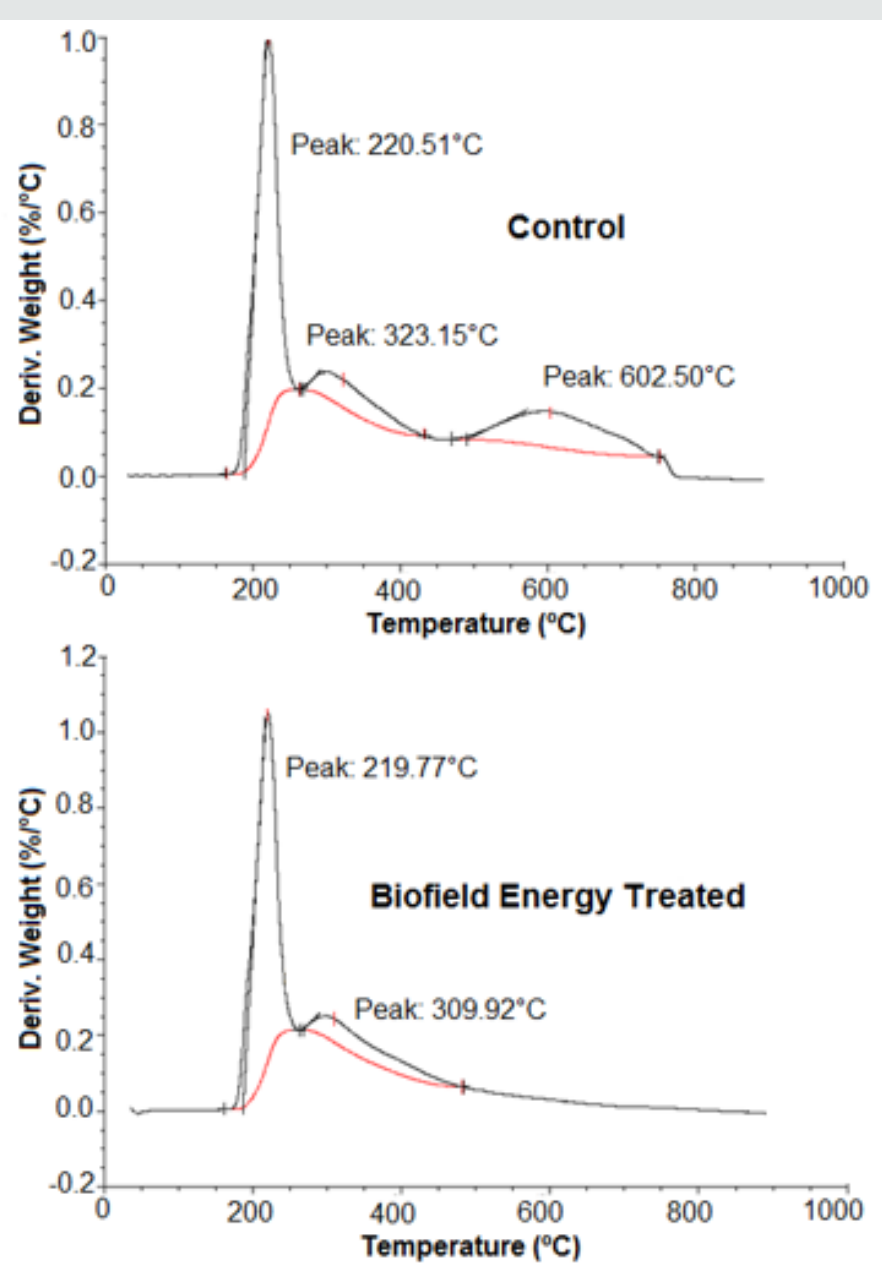

Figure 3: DTG thermograms of the control and treated ascorbic acid. 


\section{Differential Scanning Calorimetry (DSC) Analysis}

The DSC technique helps in studying the melting and other thermal behaviours of the pharmaceutical compound [40]. The literature reported that when the ascorbic acid sample was heated with the heating rate of $10{ }^{\circ} \mathrm{C} \mathrm{min}-1$, it got melted at a temperature of $193{ }^{\circ} \mathrm{C}$. Also, the DSC thermogram of ascorbic acid involves two peaks; among which, first (endothermic) peak denotes the melting of ascorbic acid, while the second (exothermic) peak is related with the thermal degradation of the ascorbic acid that also releases the volatile compounds and form a carbonaceous residue [39]. The DSC thermograms of both the samples (Figure 4) were observed similarly as reported in the literature; there was the presence of an endothermic and an exothermic peak in the thermograms of both the samples. The endothermic peak, i.e., melting temperature was observed same for both the samples; however the latent heat of fusion $(\Delta \mathrm{H})$ of the Biofield Energy Treated sample was increased by $13.74 \%$ as compared to the control ascorbic acid (Table 4).

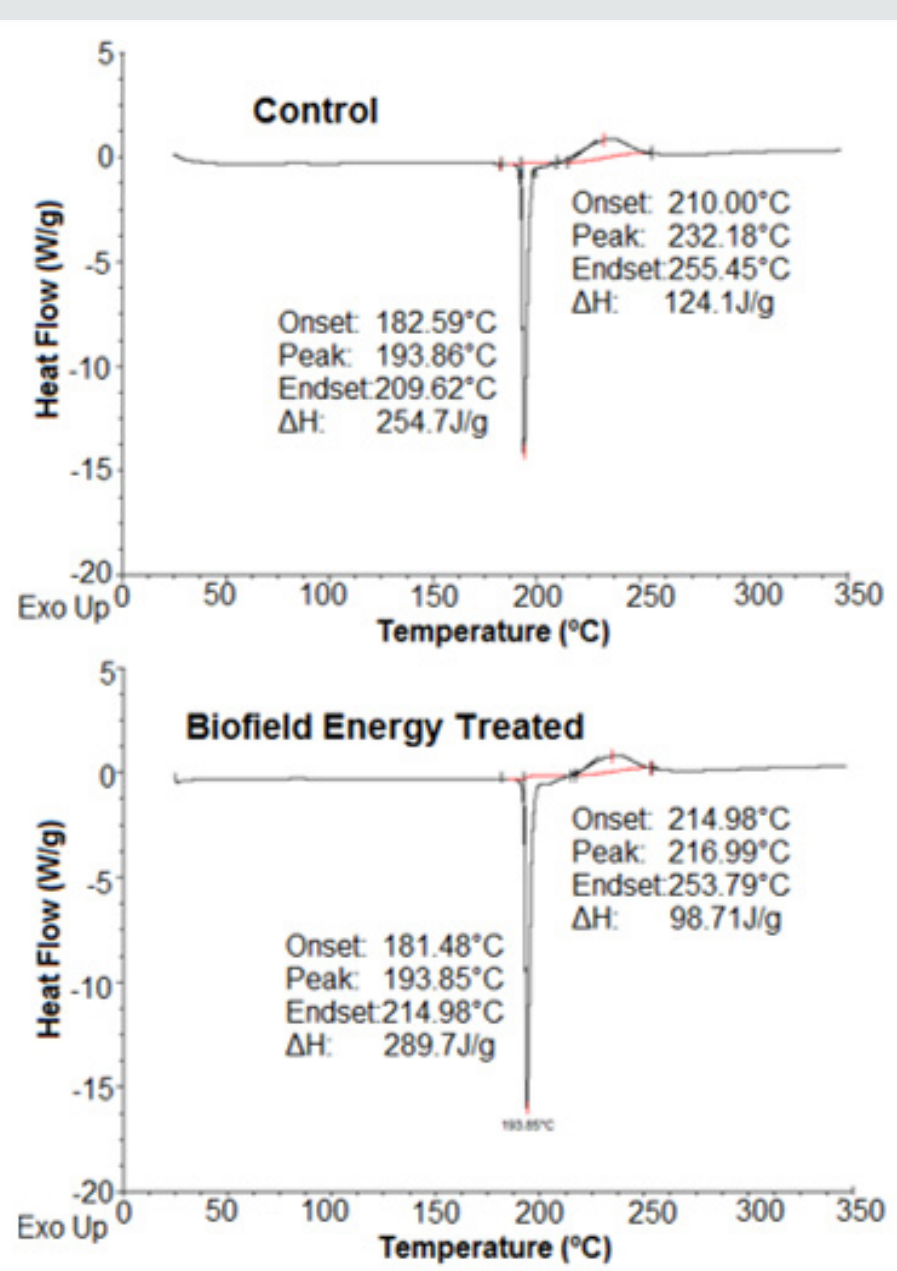

Figure 4: DSC thermograms of the control and treated ascorbic acid.

Table 4: Comparison of DSC data between the control and treated ascorbic acid.

\begin{tabular}{|cccc|}
\hline Peak & Description & Melting Point $\left({ }^{\circ} \mathbf{C}\right)$ & $\Delta \mathbf{H}(\mathbf{J} / \mathbf{g})$ \\
\hline \multirow{2}{*}{ Peak 1 } & Control sample & 193.86 & 254.70 \\
& Biofield Energy Treated sample & 193.85 & 289.70 \\
& \% Change & 0.00 & 13.74 \\
Peak 2 & Control sample & 232.18 & 124.10 \\
& Biofield Energy Treated sample & 216.99 & 98.71 \\
& \% Change & -6.54 & -20.46 \\
\hline
\end{tabular}

Besides, the broad exothermic inflection, i.e., the thermal degradation temperature in the thermogram of the Biofield Energy Treated sample was observed at $216.99{ }^{\circ} \mathrm{C}$, which was reduced by $6.54 \%$ as compared to the control sample $\left(232.18^{\circ} \mathrm{C}\right)$.
Furthermore, the $\Delta \mathrm{H}$ corresponding to this peak was observed as $124.10 \mathrm{~J} / \mathrm{g}$ and $98.71 \mathrm{~J} / \mathrm{g}$ in the control and Biofield Energy Treated sample, respectively. Thus, the $\Delta \mathrm{H}$ of decomposition was also decreased by $20.46 \%$ in the treated sample as compared 
to the control sample (Table 4). The analysis revealed that the alterations in the degradation temperature and $\Delta \mathrm{H}$ of the Biofield Energy Treated ascorbic acid sample might be due to some changes in the crystallization structure of the sample after the Biofield Energy Treatment [40]. Overall, the thermal analysis indicated the alterations in the melting and thermal stability profile of the treated sample as compared to the untreated sample.

\section{Conclusion}

The study revealed the significant impact of the Trivedi Effect ${ }^{\circledR}$ Consciousness Energy Healing Treatment on the ascorbic acid sample. The PXRD peak intensities and crystallite sizes of the Biofield Energy Treated sample significantly altered ranging from $-78.43 \%$ to $1168.06 \%$ and $-62.38 \%$ to $126.83 \%$, respectively; along with $24.99 \%$ decrease in the average crystallite size as compared to the control sample. The particle size values in the Biofield Energy Treated sample by $9.59 \%\left(\mathrm{~d}_{10}\right), 21.63 \%\left(\mathrm{~d}_{50}\right), 16.55 \%\left(\mathrm{~d}_{90}\right)$, and $17.97 \%\{\mathrm{D}(4,3)\}$, respectively; hence the specific surface area was increased by $16.67 \%$ compared to the control sample. The weight loss was increased by $6.67 \%$; however, the residue amount was found to be significantly decreased by $28.59 \%$ in the Biofield Energy Treated sample comparison to the control sample.

The $\mathrm{T}_{\max }$ corresponding to $1^{\text {st }}$ and $2^{\text {nd }}$ peaks were decreased by $0.33 \%$ and $4.09 \%$, respectively in the Biofield Energy Treated sample as compared to the control sample. Moreover, the $\Delta \mathrm{H}_{\text {fusion }}$ was significantly increased by $13.74 \%$ as compared to the control sample. Besides, the degradation temperature and $\Delta \mathrm{H}_{\text {decomposition }}$ of the Biofield Energy Treated sample were significantly reduced by $6.54 \%$ and $20.46 \%$, respectively, as compared to the control sample. The Trivedi Effect ${ }^{\circledR}$-Consciousness Energy Healing Treatment might help in forming a novel polymorphic form of ascorbic acid that may also prove to be more soluble, absorbable, and bioavailable than the untreated sample. Therefore, the Biofield Energy Treated ascorbic acid might help in preparing better nutraceutical/pharmaceutical formulations that act more efficiently for the prevention and treatment of various diseases and disorders such as diabetes, atherosclerosis, cataracts, common cold, heart diseases, glaucoma, stroke, cancer, autoimmune diseases, chronic degenerative diseases, anemia, bleeding gums, scurvy, infections, muscle degeneration, capillary haemorrhage, delayed wound healing, low immunity, atherosclerotic plaques, neurotic disturbances, etc.

\section{Acknowledgements}

The authors are grateful to Central Leather Research Institute, SIPRA Lab. Ltd., Trivedi Science, Trivedi Global, Inc., Trivedi Testimonials, and Trivedi Master Wellness for their assistance and support during this work.

\section{References}

1. Lykkesfeldt J, Michels AJ, Frei B (2014) Vitamin C. Adv Nutr 5(1): 16-18.

2. Chambial S, Dwivedi S, Shukla KK, John PJ, Sharma P (2013) Vitamin C in disease prevention and cure: An overview. Indian J Clin Biochem 28(43): 314-328.

3. Pullar JM, Carr AC, Vissers MCM (2017) The Roles of Vitamin C in skin health. Nutrients 9(8): 866.
4. Telang PS (2013) Vitamin C in dermatology. Indian Dermatol Online J 4(2): 143-146.

5. Figueroa-Méndez R, Rivas-Arancibia S (2015) Vitamin C in health and disease: Its role in the metabolism of cells and redox state in the brain. Front Physiol 6: 397.

6. Wilson JX (2005) Regulation of vitamin c transport. Ann Rev Nutr 25: 105-125.

7. Berman JD, Straus SE (2004) Implementing a research agenda for complementary and alternative medicine. Annu Rev Med 55: 239-254.

8. Hintz KJ, Yount GL, Kadar I, Schwartz G, Hammerschlag R, et al. (2003) Bioenergy definitions and research guidelines. Altern Ther Health Med 9: A13-A30.

9. Barnes PM, Bloom B, Nahin RL (2008) Complementary and alternative medicine use among adults and children: United States, 2007. Natl Health Stat Report 10(12): 1-23.

10. Jain S, Hammerschlag R, Mills P, Cohen L, Krieger R, et al., (2015) Clinical studies of biofield therapies: Summary, methodological challenges, and recommendations. Glob Adv Health Med 4: 58-66.

11. Trivedi MK, Branton A, Trivedi D, Nayak G, Bairwa K, et al., (2015) Spectroscopic characterization of disodium hydrogen orthophosphate and sodium nitrate after biofield treatment. J Chromatogr Sep Tech 6: 282.

12. Trivedi MK, Branton A, Trivedi D, Nayak G, Panda P, et al. (2016) Evaluation of the isotopic abundance ratio in biofield energy treated resorcinol using gas chromatography-mass spectrometry technique. Pharm Anal Acta 7: 481.

13. Trivedi MK , Tallapragada RM , Branton A, Trivedi D, Nayak G, et al., (2015) Potential impact of biofield treatment on atomic and physical characteristics of magnesium. Vitam Miner 3: 129.

14. Trivedi MK, Patil S, Shettigar H, Bairwa K, Jana S (2015) Effect of biofield treatment on spectral properties of paracetamol and piroxicam. ChemSci J 6: 98.

15. Trivedi MK, Branton A, Trivedi D, Nayak G, Charan S, et al., (2015) Phenotyping and 16S rDNA analysis after biofield treatment on Citrobacter braakii: A urinary pathogen. J Clin Med Genom 3: 129.

16. Trivedi MK, Patil S, Shettigar H, Mondal SC, Jana S (2015) Evaluation of biofield modality on viral load of Hepatitis B and C viruses. J Antivir Antiretrovir 7: 083-088.

17. Trivedi MK, Branton A, Trivedi D, Nayak G, Mondal SC, et al. (2015) Evaluation of plant growth, yield and yield attributes of biofield energy treated mustard (Brassica juncea) and chick pea (Cicerarietinum) seeds. Agriculture, Forestry and Fisheries. 4: 291-295.

18. Trivedi MK, Branton A, Trivedi D, Nayak G, Gangwar M, et al. (2015) Agronomic characteristics, growth analysis, and yield response of biofield treated mustard, cowpea, horse gram, and groundnuts. International Journal of Genetics and Genomics 3(6): 74-80.

19. Trivedi MK, Patil S, Tallapragada RM (2013) Effect of biofield treatment on the physical and thermal characteristics of vanadium pentoxide powders. J Material SciEng S 11: 001.

20. Trivedi MK, Tallapragada RM, Branton A, Trivedi D, Nayak G, et al. (2015) Characterization of physical and structural properties of aluminum carbide powder: Impact of biofield treatment. J Aeronaut Aerospace Eng 4: 142 .

21. Trivedi MK, Branton A, Trivedi D, Nayak G, Sethi KK, et al. (2016) Gas chromatography-mass spectrometry based isotopic abundance ratio analysis of biofield energy treated methyl-2-napthylether (Nerolin). American Journal of Physical Chemistry 5: 80-86.

22. Trivedi MK, Branton A, Trivedi D, Nayak G, Mondal SC, et al. (2015) Evaluation of biochemical marker - glutathione and DNA fingerprinting of biofield energy treated Oryza sativa. American Journal of BioScience 3: 243-248. 
23. Koster DA, Trivedi MK, Branton A, Trivedi D, Nayak G, et al. (2018) Evaluation of biofield energy treated vitamin $D_{3}$ on bone health parameters in human bone osteosarcoma cells (MG-63). Biochemistry and Molecular Biology 3: 6-14.

24. Smith DM, Trivedi MK, Branton A, Trivedi D, Nayak G, et al. (2017) Skin protective activity of consciousness energy healing treatment based herbomineral formulation. Journal of Food and Nutrition Sciences 5: 8695.

25. Singh J, Trivedi MK, Branton A, Trivedi D, Nayak G, et al. (2017) Consciousness energy healing treatment based herbomineral formulation: A safe and effective approach for skin health. American Journal of Pharmacology and Phytotherapy 2: 1-10.

26. Trivedi MK, Branton A, Trivedi D, Nayak G, Plikerd WD, et al. (2017) A Systematic study of the biofield energy healing treatment on physicochemical, thermal, structural, and behavioral properties of magnesium gluconate. International Journal of Bioorganic Chemistry 2: 135-145.

27. (1997) Desktop X-ray Diffractometer "MiniFlex+". The Rigaku Journal 14: 29-36.

28. Zhang T, Paluch K, Scalabrino G, Frankish N, Healy AM, et al. (2015) Molecular structure studies of (1S,2S)-2-benzyl-2,3-dihydro-2(1Hinden-2-yl)-1H-inden-1-ol. J Mol Struct 1083: 286-299.

29. Langford JI, Wilson AJC (1978) Scherrer after sixty years: A survey and some new results in the determination of crystallite size. J Appl Cryst 11: $102-113$

30. Trivedi MK, Sethi KK, Panda P, Jana S (2017) Physicochemical, thermal and spectroscopic characterization of sodium selenate using XRD, PSD, DSC, TGA/DTG, UV-vis, and FT-IR. Marmara Pharmaceutical Journal 21(2): 311-318.

31. Trivedi MK, Sethi KK, Panda P, Jana S (2017) A comprehensive physicochemical, thermal, and spectroscopic characterization of zinc (II) chloride using X-ray diffraction, particle size distribution, differential scanning calorimetry, thermogravimetric analysis differential thermogravimetric analysis, ultraviolet-visible, and
Fourier transform-infrared spectroscopy. International Journal of Pharmaceutical Investigation 7(1): 33-40.

32. Trivedi MK, Branton A, Trivedi D, Nayak G, Plikerd WD, et al. (2017) A systematic study of the biofield energy healing treatment on physicochemical, thermal, structural, and behavioral properties of iron sulphate. International Journal of Bioorganic Chemistry 2: 135-145.

33. Trivedi MK, Branton A, Trivedi D, Nayak G, Lee AC, et al. (2017) Evaluation of the impact of biofield energy healing treatment (the Trivedi Effect ${ }^{\circledR}$ ) on the physicochemical, thermal, structural, and behavioural properties of magnesium gluconate. International Journal of Nutrition and Food Sciences 6: 71-82.

34. Trivedi MK, Branton A, Trivedi D, Nayak G, Plikerd WD, et al. (2017) Evaluation of the physicochemical, spectral, thermal and behavioral properties of sodium selenate: influence of the energy of consciousness healing treatment. American Journal of Quantum Chemistry and Molecular Spectroscopy 2: 18-27.

35. Savjani KT, Gajjar AK, Savjani JK (2012) Drug Solubility: Importance and Enhancement Techniques. ISRN Pharmaceutics 2012.

36. Khadkaa P, Roa J, Kim H, Kim I, Kim JT, et al. (2014) Pharmaceutical particle technologies: An approach to improve drug solubility, dissolution and bioavailability. Asian J Pharm 9: 304-316.

37. Loh ZH, Samanta AK, Heng PWS (2015) Overview of milling techniques for improving the solubility of poorly water-soluble drugs. Asian J Pharm 10: 255-274.

38. Hu J, Johnston KP, Williams RO (2004) Nanoparticle engineering processes for enhancing the dissolution rates of poorly water soluble drugs. Drug Dev Ind Pharm 30: 233-245.

39. Nunes JFL, Melo DMA, de Moura MFV, de Farias RF (2007) TG-DSC study of ascorbic acid pharmaceutical formulations: Sodium croscarmellose, microcrystalline cellulose and lactose as excipients. Revista Química no Brasil 1: 7-14

40. Zhao Z, Xie M, Li Y, Chen A, Li G, et al., (2015) Formation of curcumin nanoparticles via solution enhanced dispersion by supercritical $\mathrm{CO}_{2}$. Int J Nanomedicine 10: 3171-3181.

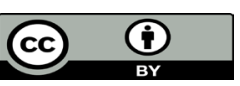

This work is licensed under Creative Commons Attribution 4.0 License

Submission Link: Submit Article

DOI: $10.32474 /$ DDIPIJ.2019.02.000149

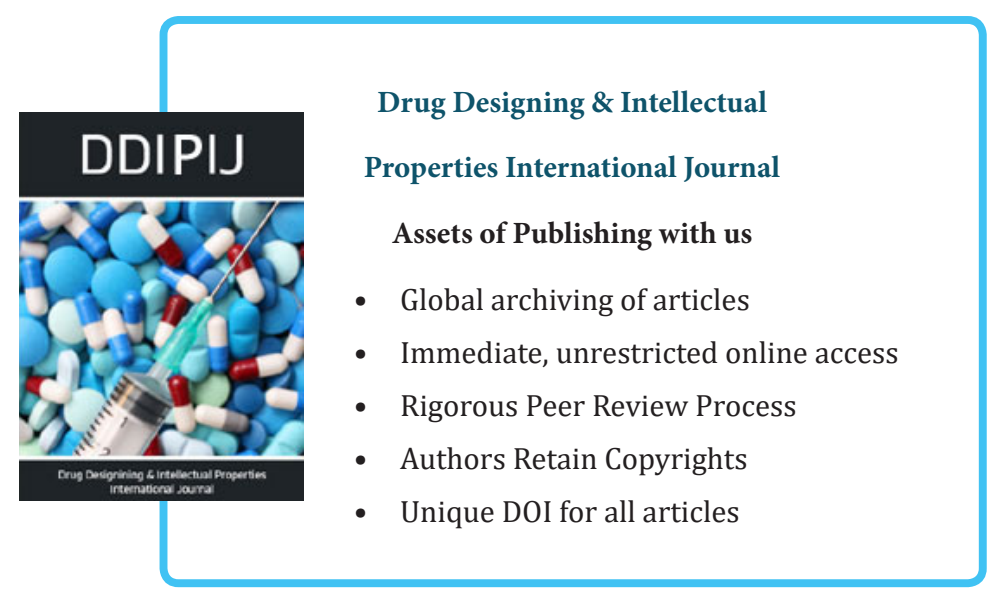

